\title{
The Effect of Programmed Physical Exercise to Attention and Working Memory Score in Medical Students
}

\author{
Kevin Fachri Muhammad, ${ }^{1}$ Anam Ong, ${ }^{2}$ Muhammad Nurhalim Shahib ${ }^{3}$ \\ ${ }^{1}$ Faculty of Medicine Universitas Padjadjaran, ${ }^{2}$ Department of Neurology Faculty of Medicine \\ Universitas Padjadjaran/Dr. Hasan Sadikin General Hospital Bandung, ${ }^{3}$ Department of \\ Biochemistry and Molecular Biology, Faculty of Medicine Universitas Padjadjaran
}

\begin{abstract}
Background: Attention and working memory are two cognitive domain crucial for activities of daily living. Physical exercise increases the level of BDNF, IGF-1, and VEGF which contributes in attention and working memory processes.This study was conducted to analyze improvement of attention and working memory after programmed physical exercise of Pendidikan Dasar XXI Atlas Medical Pioneer (Pendas XXI AMP).

Methods: An analytic observational study was conducted on 47 students from Faculty of Medicine, Universitas Padjadjaran during September-November 2012. Attention was assessed using digit span backward test, stroop test, visual search task, and trail making test. Working memory was assessed using digit span forward test and digit symbol test. Assessment was done on the 11th and 19th week of Pendas XXI AMP. Data distribution was tested first using a test of normality, and then analyzed using T-Dependent Test and Wilcoxon Test

Results: Significant improvement was noted for attention in males based on working time for stroop test (26.50 \pm 5.66 to $22.03 \pm 3.78$ seconds), working memory in males based on digit symbol test score ( $43.96 \pm 6.14$ to $53.36 \pm 5.26$ points), attention in females based on reaction time of visual search task for target absent $(0.92 \pm 0.07$ to $0.87 \pm 0.07$ seconds), and working memory in females based on digit span forward score ( $5.42 \pm 1.30$ to $6.63 \pm 1.07$ points) and digit symbol test score $(42.47 \pm 5.95$ to $53.84 \pm 5.33$ points.

Conclusions: Exercise in Pendas XXI AMP improves attention and working memory for college students in Faculty of Medicine Universitas Padjadjaran. [AMJ.2015;2(1):291-97]
\end{abstract}

Keywords: Attention, physical exercise, working memory

\section{Introduction}

Brainishumanbodilyorganwhichisresponsible in controlling sensory function, behaviour, and cognitive attributes. By transforming external stimuli into neuronal impulses, human brain builds an internal representation of the outside environment. ${ }^{1}$ Sensory input will become a sequence of information and it will be processed in the brain until an internal representation is developed. This process is called cognitive function. ${ }^{2}$ Cognitive domain derives attention and working memory, which are the most utilized function for activities of daily living. ${ }^{3}$

Attention is defined as a maintenance of awareness toward external stimuli or internal thoughts within a certain amount of time while ruling out various sensation and thoughts that might interrupt this process. This ability enables a person to focus on a constant thought or action. ${ }^{3}$ Working memory is a more specific function in the prefrontal area of the brain that is defined by psychologist and neurologist as an elaboration of thoughts. Prefrontal area has the ability to store various pieces of information together in a certain time and recall this information in a split second when needed. Thus, working memory affects (1) the ability to predict, (2) to slow down incoming sensory signal so that information can be processed to determine the best response, (3) to consider consequences of motor actions prior to the implementation of motion, (4) to solve mathematical, legal, or philosophical question, (5) to correlate bits of information when a person faces problems that they never experienced before, and (6) activities controlling. ${ }^{2}$

Attention and working memory capacity are varied for each individual. Variations in the ability to manage attention and utilize working memory can be influenced by several

Correspondence: Kevin Fachri Muhammad, Faculty of Medicine, Universitas Padjadjaran, Jalan Raya BandungSumedang Km.21, Jatinangor, Sumedang, Indonesia, Phone: +6281317877792 Email: kevinfachri@gmail.com 
things; namely gender, age, genetic, nutrition, emotion, motivation, job, education, and physical activity. There are anatomical and physiological differences in attention and working memory in men and women. This happened because women have more extensive connection between brain hemispheres in the corpus callosum than men have. Women also have larger region of language associations, named Wernicke and Broca's area.

The neuropeptide vasopressin which are used to boost attachment of information is more readily found in men than in women. Then, there is the difference in circulating sex hormones. Estradiol, a steroid hormones which is circulating in women has been reported to improve verbal cognition, while testosterone which is circulating in men has the effect to improve spatial cognition. ${ }^{4}$

A person will experience a decreased body homeostatic function based on age. Regulation of information, learning speed, and the reaction speed to simple and complex stimuli will continue to deteriorate. Progression of this deterioration is influenced by genetic factors. ${ }^{5}$ Nutrition is another factor that affects cognitive status. The brain requires glucose for metabolic function. Decrease intake of glucose will decrease brain tissue performance and thus affecting cognitive function. ${ }^{6}$ Caffeine and theanin, which is found in coffee and tea respectively, can increase locomotor activity, emotions, concentration, and attention because it can affect the neurotransmitter dopamine, serotonin, glutamate, and gammaamino butyric acid. ${ }^{7,8}$ The next factor, according to Thompson and Tulving, are emotion and motivation, that they are sharing part in the encoding specificity. When the information is stored in a particular emotional or motivational state it will be easier if the emotions and motivations are also reproduced if this information is to be recalled. ${ }^{9}$ Sufficient sleep contributes in the well-being of prefrontal cortex area. According to Horne in Alhola and Polo-Kantola ${ }^{10}$ individuals who experience sleep deprivation will have decreased function governed by the prefrontal cortex such as executive function, language, and divergent thinking.

Work and education may affect a person's attention and working memory especially in jobs that requires concentration and quick decision making, forcing the person to constantly use their attention and working memory so they become more adept in utilizing its function. ${ }^{11}$

Kramer et al. in Lambourne ${ }^{12}$ states that physical exercise in adults is associated with increased executive control function such as coordination, planning, attention, and working memory. In addition, exercise also influence aspects of inhibitory control that allows individual to restrict the access of information which is considered irrelevant to the response that will be given to the outside world. Based on the study by Hogervost et al. in Pontifex et al. $^{13}$, subjects undergoing acute aerobic exercise with intensity of $70 \%$ of maximal heart rate gives better results when performed the Stroop effect test, a test that assess the ability of a subject in selecting information. While Krus et al. in Pontifex et al. ${ }^{13}$ study shows the increase in perceptual sensitivity from the subjects after they undergo anaerobic exercise in which subjects were asked to press a spring board for 20 seconds. According to Lambourne $^{12}$, who cited Chodzko-Zajko and Madden et al. study, exercise can provide a positive effect on cognitive function because it can increase collateral vacularization, thus increasing blood flow to the brain, which provide an important supply of nutrients such as glucose and oxygen. While the results on animal models by Black et al. and van Praag et al. in Lambourne ${ }^{12}$ showed that exercise affect cognitive function because it can induce the development of neuronal connections in the brain structures such as cerebral cortex and hippocampus.

Pendidikan Dasar XXI Atlas Medical Pioneer (Pendas XXI AMP) Faculty of Medicine Universitas Padjadjaran is one form of exercise that aims to train the physical abilities of its participants through programmed physical exercise that lasted for 19 weeks. The program consisted of aerobic exercise in a form of run and load-walk, and anaerobic exercise in a form of sprints, push-ups, sit-ups, bending, and pull-ups. Participants of Pendas XXI AMP have uniformity in the form of exercise they undergo and they were also directed to be discipline in following the program, so the study population is very homogenous.

Exercise patterns performed on Pendas XXI AMP were different from exercise performed in previous studies whichonly emphasizes aerobic activity, because physical exercise in Pendas XXI AMP consisted of aerobic and anaerobic activity. ${ }^{14}$ In this study observation was done for 8 weeks, from week 11 to week 19 of Pendas XXI AMP, because in this time window the exercise was programmed to have constant duration, frequency, intensity, and type. In this study, subjects are divided by sex, which is men and women, because there 
Kevin Fachri Muhammad, Anam Ong, Muhammad Nurhalim Shahib: The Effect of Programmed Physical 293 Exercise to Attention and Working Memory Score in Medical Students

are differences in the structure and cognitive abilities between the two.

\section{Methods}

Population of this study were students from Faculty of Medicine Universitas Padjadjaran who participated in physical exercise program of Pendidikan Dasar XXI Atlas Medical Pioneer (Pendas XXI AMP). Subjects were selected with a total sampling method, and were divided by sex. The inclusion criteria were, (1) subjects must registered and participated in Pendas XXI AMP, (2) subjects must completed an informed consent. While the exclusion criteria of this study were (1) attending aerobic or anaerobic exercises 3 times a week outside Pendas XXI AMP, (2) did not follow Pendas XXI AMP until the end, (3) performed strenuous physical activity 24 hours prior to measurement,(4) not getting enough sleep the night before measurement, (5) consumed food or beverages containing caffeine or theanin 48 hours prior to measurement.

This study was analytic observational study to determine the increase in attention and working memory scores from measurements taken at week 11 and week 19 of Pendas XXI AMP. Measurement of attention score was done using 4 type of tests, namely Digit Span Backward Test, Stroop Test, Visual Search Task, and Trail Making Test. Measurement of working memory score was done using 2 type of tests, namely Digit Span Forward Test and Digit Symbol Test. Attention and working memory score were categorized as increased if there is at least one test which has significant increase at week 19 measurement and other tests did not decline. The study was conducted from September-November 2012 at campus of Faculty of Medicine Universitas Padjadjaran Jatinangor. Data distribution was tested first using a test of normality, and then analyzed using T-Dependent Test and Wilcoxon Test. Processing of data was done using SPSS Statistic Software version 20.0

\section{Results}

This study deals with 47 subjects, consisted of
28 men and 19 women. The range of age of the subjects varied between 18-22 years old. The average age of these subjects are 19 years old (Table 1).

Analysis of male students attention and working memory score from measurements taken at week 11 and week 19 are respectively (Table 2,Table 3). There was a significant improvement $(\mathrm{p} \leq 0.05)$ from the scores of attention in male students according to Stroop Test working time $(26.50 \pm 5.66$ to $22.03 \pm 3.78$ seconds) with an average working time reduction of $4.47 \pm 6.89$ seconds. Improvement also occurred in the result of Digit Span Backward Test scores (4.36 \pm 1.37 to $4.75 \pm 1.53$ points), time spent on Trail Making Test part A $(21.51 \pm 11.47$ to $18.51 \pm 11.97$ seconds), time spent on Trail Making Test part B ( $40.75 \pm 24.15$ to $36.55 \pm 19.18$ seconds), reaction time for Visual Search Task for Target Present ( $0.95 \pm 0.79$ to $0.94 \pm 0.11$ seconds), and reaction time Visual Search Task for Target Absent $(1.29 \pm 0.81$ to $1.30 \pm 0.15$ seconds), but this improvement was not statistically significant (Table 2).

There was a significant increase ( $p \leq 0.05)$ from the scores of working memory in male students according to Digit Symbol Test score (43.96 \pm 6.14 to $53.36 \pm 5.26$ points) with an average score increase of $9.39 \pm 8.27$ points. Improvement also occurred in the results of Digit Span Forward Test scores $(5.64 \pm 1.34$ to $6.21 \pm 1.23$ points), but this improvement was not statistically significant (Table 3 ). Analysis of female students attention and working memory score from measurements taken at week 11 and week 19 are respectively (Table 4, Table 5).

There was a significant improvement $(\mathrm{p} \leq$ 0.05 ) from the scores of attention in female students according to Visual Search Task for Target Absent reaction time $(0.92 \pm 0$, 07 to $0.87 \pm 0.07$ seconds) with an average reaction time reduction of $0.05 \pm 0.08$ seconds. Improvement also occurred in the result of Digit Span Backward Test scores $(4.47 \pm 1.65$ to $5.16 \pm 1.38$ points), time spent on Trail Making Test part B $(41.26 \pm 9.03$ to $39.60 \pm 12$, 28 seconds), time spent on Stroop Test $(26.21 \pm 5.68$ to $23.02 \pm 3.47$ seconds), and reaction time forVisual Search Task for Target

Table 1 Profile of gender and age

\begin{tabular}{lccc}
\hline \multicolumn{1}{c}{ Sex } & $\mathbf{N}$ & Average age & Median (Minimum-Maximum) \\
Male & 28 & $19,36+1,2$ & $19(18-22)$ \\
Female & 19 & $19,42+0,9$ & $19(18-21)$ \\
\hline
\end{tabular}


Table 2 Male students attention score difference between week 11 and week 19

\begin{tabular}{|c|c|c|c|c|c|c|}
\hline Variable & $\begin{array}{c}\text { Type of } \\
\text { Test }\end{array}$ & $\mathbf{N}$ & $\begin{array}{c}\text { Mean } \\
\text { Score } \pm S . D .\end{array}$ & $\begin{array}{c}\text { Mean } \\
\text { Difference } \pm \text { S.D. } \\
\text { / Median } \\
\text { (Minimum- } \\
\text { Maximum) } \\
\end{array}$ & $\begin{array}{c}\text { Confidence } \\
\text { Interval } \\
95 \%\end{array}$ & $\mathbf{p}$ \\
\hline \multirow{2}{*}{$\begin{array}{c}\text { Digit Span } \\
\text { Backward Test } \\
\text { (score) }\end{array}$} & pre-test & 28 & $4,36 \pm 1,37$ & $0,39 \pm 2,30$ & $-0,50-1,28$ & $0,374^{*}$ \\
\hline & post-test & 28 & $4,75 \pm 1,53$ & & & \\
\hline \multirow{2}{*}{$\begin{array}{l}\text { Stroop Test } \\
\text { (seconds) }\end{array}$} & pre-test & 28 & $26,50 \pm 5,66$ & $-4,47 \pm 6,89$ & $-7,14-(-1,0)$ & $0,002^{*}$ \\
\hline & post-test & 28 & $22,03 \pm 3,78$ & & & \\
\hline \multirow{2}{*}{$\begin{array}{l}\text { Trail Making Test } \\
\text { part A (seconds) }\end{array}$} & pre test & 28 & $21,51 \pm 11,47$ & $21,93(11,47-29,36)$ & - & $0,056^{* *}$ \\
\hline & post test & 28 & $18,51 \pm 11,97$ & $17,84(11,97-28,31)$ & - & \\
\hline \multirow{2}{*}{$\begin{array}{l}\text { Trail Making Test } \\
\text { part B (seconds) }\end{array}$} & pre test & 28 & $40,75 \pm 24,15$ & $36,56(24,16-57,65)$ & - & $0,127^{* *}$ \\
\hline & post test & 28 & $36,55 \pm 19,18$ & $36,48(19,18-55,98)$ & - & \\
\hline \multirow{2}{*}{$\begin{array}{l}\text { Visual Search Task } \\
\text { for Target Present } \\
\text { (seconds) }\end{array}$} & pre test & 28 & $0,95 \pm 0,79$ & $0,93(0,79-1,14)$ & - & $0,873^{* *}$ \\
\hline & post test & 28 & $0,94 \pm 0,11$ & $0,93(0,74-1,11)$ & - & \\
\hline \multirow{2}{*}{$\begin{array}{l}\text { Visual Search Task } \\
\text { for Target Absent } \\
\text { (seconds) }\end{array}$} & pre test & 28 & $1,29 \pm 0,81$ & $1,29(0,81-2,45)$ & - & $0,593^{* *}$ \\
\hline & post test & 28 & $1,30 \pm 0,15$ & $1,31(0,99-1,54)$ & - & \\
\hline
\end{tabular}

Note: ${ }^{*}=$ tested with $\mathrm{t}$-dependent test, ${ }^{* *}=$ tested with wilcoxon test

Present $(0.84 \pm 0.05$ to $0.80 \pm 0.07$ seconds) but this improvement was not statistically significant (Table 4).

There were a significant increase $(\mathrm{p} \leq 0.05)$ from the scores of working memory in male students according toDigit Symbol Test scores (42.47 \pm 5.95 to $53.84 \pm 5.33$ points) with an average score increase of $11.37 \pm 7.67$ and Digit Span Forward scores $(5.42 \pm 1.30$ to $6.63 \pm 1.07)$ (Table 5).

Table 3 Male Students Working Memory Score Difference between Week 11 and Week 19

\begin{tabular}{|c|c|c|c|c|c|c|}
\hline Variable & Type of Test & $\mathbf{N}$ & $\begin{array}{c}\text { Mean } \\
\text { Score } \pm S . D .\end{array}$ & $\begin{array}{c}\text { Mean } \\
\text { Difference } \pm \text { S.D. } \\
\text { /Median } \\
\text { (Minimum- } \\
\text { Maximum) }\end{array}$ & $\begin{array}{c}\text { Confidence } \\
\text { Interval 95\% }\end{array}$ & p \\
\hline \multirow{2}{*}{$\begin{array}{c}\text { Digit Symbol Test } \\
\text { (score) }\end{array}$} & pre-test & 28 & $43,96 \pm 6,14$ & $9,39 \pm 8,27$ & $6,19-12,60$ & $0,000^{*}$ \\
\hline & post-test & 28 & $53,36 \pm 5,26$ & & & \\
\hline \multirow{2}{*}{$\begin{array}{l}\text { Digit Span } \\
\text { Forward Test } \\
\text { (score) }\end{array}$} & pre-test & 28 & $5,64 \pm 1,34$ & $6(3-8)$ & & $0,100 * *$ \\
\hline & post-test & 28 & $6,21 \pm 1,23$ & $6(4-8)$ & & \\
\hline
\end{tabular}


Table 4 Female Students Attention Score Difference between Week 11 and Week 19

\begin{tabular}{|c|c|c|c|c|c|c|}
\hline Variable & $\begin{array}{l}\text { Type of } \\
\text { Test }\end{array}$ & $\mathbf{N}$ & $\begin{array}{c}\text { Mean } \\
\text { Score } \pm S . D .\end{array}$ & $\begin{array}{c}\text { Mean } \\
\text { Difference } \pm \text { S.D. } \\
\text { /Median } \\
\text { (Minimum- } \\
\text { Maximum) }\end{array}$ & $\begin{array}{c}\text { Confidence } \\
\text { Interval } \\
95 \%\end{array}$ & $\mathbf{p}$ \\
\hline \multirow{2}{*}{$\begin{array}{l}\text { Digit Span } \\
\text { Backward Test } \\
\text { (score) }\end{array}$} & pre-test & 19 & $4,47 \pm 1,65$ & $0,68 \pm 1,97$ & $-0,27-1,64$ & $0,148^{*}$ \\
\hline & post-test & 19 & $5,16 \pm 1,38$ & & & \\
\hline \multirow{2}{*}{$\begin{array}{l}\text { Stroop Test } \\
\text { (seconds) }\end{array}$} & pre-test & 19 & $41,26 \pm 9,03$ & $-1,66 \pm 13,72$ & $-8,27-4,96$ & $0,605^{*}$ \\
\hline & post-test & 19 & $39,60 \pm 12,28$ & & & \\
\hline \multirow{2}{*}{$\begin{array}{l}\text { Trail Making Test } \\
\text { part A (seconds) }\end{array}$} & pre test & 19 & $26,21 \pm 5,68$ & $-3,19 \pm 7,52$ & $-6,81-0,43$ & $0,081^{*}$ \\
\hline & post test & 19 & $23,02 \pm 3,47$ & & & \\
\hline \multirow{2}{*}{$\begin{array}{l}\text { Trail Making Test } \\
\text { part B (seconds) }\end{array}$} & pre test & 19 & $0,84 \pm 0,05$ & $-0,04 \pm 0,09$ & $-0,08-0,00$ & $0,079 *$ \\
\hline & post test & 19 & $0,80 \pm 0,07$ & & & \\
\hline \multirow{2}{*}{$\begin{array}{l}\text { Visual Search } \\
\text { Task for } \\
\text { Target Present } \\
\text { (seconds) }\end{array}$} & pre test & 19 & $0,92 \pm 0,07$ & $-0,05 \pm 0,08$ & $-0,08-0,01$ & $0,011^{*}$ \\
\hline & post test & 19 & $0,87 \pm 0,07$ & & & \\
\hline \multirow{2}{*}{$\begin{array}{l}\text { Visual Search } \\
\text { Task for Target } \\
\text { Absent (seconds) }\end{array}$} & pre test & 19 & $19,98 \pm 5,70$ & $19,06(11,36-27,9)$ & - & $0,528^{* *}$ \\
\hline & post test & 19 & $19,88 \pm 4,81$ & $18,39(13,14-27,78)$ & - & \\
\hline
\end{tabular}

\section{Discussions}

The results showed that the students of Faculty of Medicine Universitas Padjadjaran who participates in physical exercise program of Pendas XXI AMP have increased attention and working memory scores. Attention is the process that occurs when human brain is focused on one specific stimulus. The information obtained can be derived from the process of sensing and memory. Attention capacity improves the ability to efficiently

Table 5 Female Students Working Memory Score Difference between Week 11 and Week 19

\begin{tabular}{|c|c|c|c|c|c|c|}
\hline Variable & Type of Test & $\mathbf{N}$ & $\begin{array}{c}\text { Mean } \\
\text { Score } \pm S . D .\end{array}$ & $\begin{array}{c}\text { Mean } \\
\text { Difference } \pm \text { S.D. } \\
\text { / Median } \\
\text { (Minimum- } \\
\text { Maximum) }\end{array}$ & $\begin{array}{c}\text { Confidence } \\
\text { Interval 95\% }\end{array}$ & $\mathbf{p}$ \\
\hline \multirow{2}{*}{$\begin{array}{l}\text { Digit Symbol Test } \\
\text { (score) }\end{array}$} & pre-test & 19 & $42,47 \pm 5,95$ & $11,37 \pm 7,67$ & $7,67-15,06$ & $0,000^{*}$ \\
\hline & post-test & 19 & $53,84 \pm 5,33$ & & & \\
\hline \multirow{2}{*}{$\begin{array}{l}\text { Digit Span } \\
\text { Forward Test } \\
\text { (score) }\end{array}$} & pre-test & 19 & $5,42 \pm 1,30$ & $5(3-7)$ & - & $0,003^{* *}$ \\
\hline & post-test & 19 & $6,63 \pm 1,07$ & $7(4-8)$ & - & \\
\hline
\end{tabular}

Note: ${ }^{*}=$ tested with t-dependent test, ${ }^{* *}=$ tested with wilcoxon test 
sort out which information is needed and which should be ignored. Neuroimage studies documenting part of the frontal lobe, especially in the right hemisphere, is essential in maintaining attention. ${ }^{2,15,16}$ Working memory is part of executive function that is useful for decision making when a person is exposed to a certain environment. Working memory may manipulate the information and use it to achieve specific objectives. ${ }^{16}$

Exercise induces neuronal changes. The regulatory mechanisms that initiate neuronal changes are Brain-Derived Neurotrophic Factor (BDNF), Insulin Growth Factor 1 (IGF-1), and Vascular Endothelial Growth Factor (VEGF). BDNF mRNA and BDNF protein increased in the area around the hippocampus after a few days working out and will remain high during sustained exercise. Signalling by BDNF is what facilitates long-term potentiation and activate MAPK (Mitogen-Activated Protein Kinase), a signal transduction pathway that is important for long-term potentiation in the hippocampus. BDNF also induce neurogenesis, where the neural progenitor will increase its number in the hippocampus. This young nerve cells have a low threshold of excitability that is effective in conducting action potential. The role of IGF-1 is to increase levels of Trk-B (TyrosineRelated Kinase B), the receptor for BDNF, thus increases BDNF signalling and promotes neuronal plasticity. Furthermore IGF-1 is an important factor for oligodendrocyte and neuronal durability, as well as for the growth and differentiation of neurons. VEGF induces potential mitotic activity of endothelial cells in blood vessels, thereby increasing proliferation, durability, adhesion, migration, and capillary tube formation. ${ }^{17,18}$

Exercise-induced neurotrophic effects varied between each different individuals, and is limited in some way. Sibley and Beilock describes through their study thatacute aerobic exercise will only increase the capability of working memory in people which previously had a low working memory capabilities, while in people who already had a good working memory capacity this enhancement effect will not be significant. ${ }^{19}$ Pontifex, et al. ${ }^{13}$ explained that exercise-induced development in cognitive abilites will be effective if the exercise was done with mild or moderate intensity according to the percentage of maximal heart rate of the individual.

With the conditioning conducted for 11 weeks before the tests began, the subjects have already been accustomed with physical exercise program of Pendas XXI AMP. The physical exercise program conducted from the 11th through $19^{\text {th }}$ week of Pendas XXI AMP was specifically constructed so its intensity ranged between moderate-to-somewhat hard based on exertion rating scale method of intensity measurement. Tests of attention and working memory scores which shows insignificant results may not be caused by the exercise intensity, but may be caused by the subjects in general which already have a pretty good ability in the management of attention and utilization of working memory, so that the effect of exercise become more limited.

\section{References}

1. Sadock BJ, Sadock VA. Kaplan \& Sadock's synopsis of psychiatry: behavioral science/ clinical psychiatry. 10th ed. New York: Lippincot William \& Wilkins; 2007.

2. Guyton AC, Hall JE. Textbook of medical physiology. 11th ed. Philadelphia: Elsevier Saunders; 2006.

3. Ropper AH, Brown RH. Adams and Victor's principles of neurology. 8thed. New York: The McGraw Hill Companies, Inc.; 2005.

4. Boureau Y-L. Developmental mechanism leading to cognitive disparities between men and women. 2005. [Cited 2012 December 10]. Available from: http:// cs.nyu.edu/ ylan/files/malesFemales05. pdf.

5. Lee S, Kawachi I, Berkman L, Grodstein F. Education, other socioeconomic indicator and cognitive function. Am J Epidemiol. 2003;157(8):712-20.

6. Bingham EM, Hopkins D, Smith D, Pernet A, Hallett W, Reed L, et al. The role of insulin in human brain glucose metabolism: an 18fluoro-deoxyglucose positron emission tomography study. Diabetes. 2002;51(12):3384-90.

7. Nobre AC, Rao A, Owen GN. L-theanine, a natural constituent in tea, and its effect on mental state. Asia Pac J Clin Nutr. 2008;17 Suppl 1:167-8.

8. van Boxtel MP, Schmitt JA, Bosma H, Jolles J. The effect of habitual caffeine use on cognitive change: a longitudinal perspective. Pharmacol Biochem Behav. 2003;75(4):921-7.

9. Eysenck MW, Keane MT. Cognitive Psychology: a Student's Handbook. 5th ed. Hove: Psychology Press; 2009.

10. Alhola P, Polo-Kantola P. Sleep deprivation: impact on cognitive performance. Neuropsychiatr Dis Treat. 2007;3(5):553- 
67.

11. Alvarado B, Zunzunegui M, Del Ser T, Beland F. Cognitive decline is related to education and occupation in a Spanish elderly cohort. Aging Clin Exp Res. 2002;14(2):132-42.

12. Lambourne K. The relationship between working memory capacity and physical activity rates in young adults. J Sports Sci Med. 2006;5(1):149-53.

13. Pontifex MB, Hillman $\mathrm{CH}$, Fernhall B, Thompson KM, Valentini TA. The effect of acute aerobic and resistance exercise on working memory. Med Sci Sports Exerc. 2009;41(4):927-34.

14. Muhammad KF. Program pembinaan jasmani Pendidikan Dasar XXI Atlas Medical Pioneer. 1st ed. Bandung: Dewan Pengurus XIX Atlas Medical Pioneer; 2012.
15. Sternberg RJ. Cognitive psychology. 5thed. Bellmont: Wadsworth Thomson Learning; 2009.

16. Kay J, Tasman A. Essential of psychiatry. 1st ed. Chichester: John Wiley and Sons, Ltd; 2006.

17. Cotman CW, Berchtold NC, Christie L-A. Exercise builds brain health: key roles of growth factor cascades and inflammation. Trends Neurosci. 2007;30(9):464-72.

18. Cotman CW, Berchtold NC. Exercise: a behavioral intervention to enhance brain health and plasticity. Trends Neurosci. 2002;25(6):295-301.

19. Sibley BA, Beilock SL. Exercise and working memory: an individual differences investigation. J Sport Exerc Psychol. 2007;29(6):783-391 